UDC 330.341 .42

JEL Classification: EOO

DOI: 10.15587/2312-8372.2019.176907

Nikitin Y.,
Kulchytskyy 0.

\title{
STRATEGY OF THE DEVELOPMENT OF INDUSTRY 4.0 IN UKRAINE: EVALUATION OF THE REPRESENTATIVES OF VARIOUS ORGANIZATIONS AND COMPANIES OF UKRAINE
}

Об’єктом дослідження є украӥнсъка стратегія Індустрії 4.0. Важливим етапом розвитку руху «Індустрія 4.0 в Україні» стало представлення украӥнської стратегї Індустрії 4.0. Тому надзвичайно важливим $\epsilon$ ощінка представників різних організацій та компаній України щодо пріоритетів стратегї розвитку «ндустрії 4.0» в Україні.

В ході дослідження використовувалось анкетне опитування декількох блоків питань:

- «Необхідність застосування підходів Індустрії 4.0 у національних стратегіях Украӥни»;

- «Визначення галузей, де Украйна має найкращі шанси зайняти передові позицї щодо розвитку підходів Індустрії 4.0 на міжнародній арені»;

- «Ключові фактори успіху стратегї Індустрії 4.0 в Україні»;

- «Гловні стратегічні ініціативи розвитку Індустрії 4.0 в Україні».

В опитуванні взяли участь 122 респондентів. Отримано результати опитування бачення представників різних організацій та компаній України щодо стратегї розвитку Індустрії 4.0 в Україні $і$ ї семи головних стратегічних ініціатив:

1) інституціоналізащія розвитку промислових хай тек сегментів на рівні держави;

2) створення інноваційної екосистеми промислових хай тек;

3) прискорення кластеризацї у сфері Індустрії 4.0;

4) повномасштабна цифровізація ключових секторів промисловості, енергетики, інфраструктури;

5) максимальна інтеграція Індустрії 4.0 в стратегї оборонного комплексу та безпеки країни;

6) запуск експортних програм для промислових хай тек секторів;

7) інтернаціоналізащія та інтегращія у світовий простір Індустрії 4.0.

Завдяки иьому було визначено першочергові заходи впровадження української стратегї̈ Індустрії 4.0 з врахуванням бачення представників різних зацікавлених сторін. Зокрема, першочергові заходи стосуються підвищення цифрових навичків, стандартизацї, створення екосистеми, фінансових інструментів стимулювання, програм інтеграцї̈ в Свропейський Союз, трансферу технологій та ін.

Ключові слова: Індустрія 4.0 в Україні, стратегічні інічіативи, ключові напрями розвитку, першочергові заходи.

\section{Introduction}

Industry 4.0 refers to the intelligent networking of machines and processes in the industry with the help of information and communication technology. There are many ways for companies to use intelligent networking. The possibilities include, for example: flexible production, convertible factory, customer-centric solutions, use of data, optimized logistics, resource-efficient circular economy [1].

Industry 4.0, as a tool for improving the competitiveness of enterprises in the fourth industrial revolution provides the basis for the creation of factories 4.0. It also creates the basis for the formation of industrial high tech and the development of smart cities and smart regions.
Taking into account international trends, the development of the digital economy should become a priority for Ukraine. However, today the introduction of the digital economy in Ukraine is actually narrowing down to the development of communication and information networks. The reason for this is because the digital infrastructure in Ukraine is completely underdeveloped and there is a general syndrome of «obsolete technologies».

Association of Industrial Automation of Ukraine (AIAU), as the founder of the «Industry 4.0 in Ukraine» movement, actively stimulates key strategic initiatives and directions of the development of the «Industry 4.0 in Ukraine» movement. And the involvement of the representatives of various organizations and companies of Ukraine for 
evaluation and discussion of the priorities of strategy of the development Industry 4.0 in Ukraine is actually.

\section{The object of research and its technological audit}

The object of research is Ukrainian Industry 4.0 strategy. Implementing Industry 4.0 is a complex project: the more processes the economy digitizes and networks, the more interfaces are created between different actors. Uniform norms and standards for different industrial sectors, IT security and data protection play an equally central role as the legal framework, the changes in education and work, the development of new business models and the necessary research.

An important step in the development of the movement «Industry 4.0 in Ukraine» was to present the Ukrainian Industry 4.0 strategy. The strategy identified key success factors, main directions of strategic development.

\section{The aim and objectives of research}

The aim of research is evaluation of the vision by representatives of various organizations and companies of Ukraine on the priorities the of strategy of the development Industry 4.0 in Ukraine. In order to achieve this aim, it is necessary to perform the following objectives:

1. Develop the questionnaire to access the vision of various stakeholders on the development of Industry 4.0 strategy in Ukraine.

2. Use the questionnaire to conduct the survey among representatives of various organizations and companies of Ukraine.

3. Analyze the results of the evaluation of the representatives of various organizations and companies of Ukraine about priorities of strategy of the development Industry 4.0 in Ukraine.

\section{Research of existing solutions of the problem}

The Industry 4.0 concept was initiated by the German science and business community in 2011 as a tool for improving the competitiveness of the German manufacturing industry. The plan was in enhancing the integration of cyber-physics systems in all production processes, providing their interaction in real-time and forming the basis for the creation of factories 4.0 [1].

The substantial advantage of «Industry 4.0» is the possibility of its phased introduction at industrial enterprises. At the initial stage, the re-equipment can begin with several units of equipment, and then extend it through the growing introduction of cyber-physics systems [1]

In 2016, PricewaterhouseCoopers conducted a global Industry 4.0 survey. It was the biggest worldwide survey of its kind, with over 2,000 participants from nine major industrial sectors and 26 countries. The study explored the benefits of digitizing company's horizontal and vertical value chains, as well as building digital product \& service portfolio. Based on the findings the blueprint for success to help secure company's position as a leading digital enterprise in tomorrow's complex industrial ecosystems was prepared [2].

Another survey was conducted by Deloitte to understand how companies are investing in Industry 4.0 to enable digital transformation. Deloitte fielded a global survey of 361 executives in 11 countries in the Americas, Asia, and
Europe. The survey revealed a mix of ambitious plans for future investment as well as issues. The authors observed paradoxes around strategy, supply chain transformation, talent readiness, and drivers for investment [3].

On the other hand, experts from the Acatech study are considering threats of Industry 4.0. There is a risk of developing products that lack market relevance. In addition, all the countries in the survey were concerned about data security and data sovereignty [4].

The authors of recommendations [5] for implementing the strategic initiative Industry 4.0 suggest to implement a dual strategy to become a leading market and supplier. The leading supplier strategy addresses the potential of Industry 4.0 from the point of view of the equipment supplier industry. The leading market for Industry 4.0 is country's domestic manufacturing industry.

Indeed, in the scope of Industry 4.0 the main element is Industrial Internet of Things with its many components, from Internet of Things (IoT) platforms to Industrial IoT gateways and devices etc. However, besides IoT and cyberphysics systems the Industry 4.0 also relies on many other technologies. These technologies are: cloud computing and platforms, big data and advanced data analytics, artificial intelligence, mobile, data communication/network technologies, manufacturing execution systems, enterprise resource planning, programmable logic controllers, sensors and actuators and innovative data exchange models [6].

This allows to turn the entire enterprise without stopping it. Transformation of an enterprise means the introduction of cyberphysical systems: equipment with sensors, system components, intelligent robots, which work together with the personnel [7]. In the United States, as well, investments in digitalization of production are increasing [8]. In China, an industrial concept that aims at automating digital manufacturing processes and creating industries of the fourth industrial form is used. In Japan, there is a digital transformation of manufacturing enterprises, aimed at increasing operational efficiency, cost reduction and quality control [9].

The digital economy can become the basis of the economic jump of Ukraine. Gradual transition to electronic accounting and management, introduction to the international online business [10].

By making a «digital leap», Ukraine can become a place for ambitious projects of digital transformations in infrastructure, industry, and all spheres of life.

National movement «Industry 4.0 in Ukraine» has been created as a common platform for:

- industrial high tech sectors;

- machine and instrument builders;

- designers;

- engineering companies;

- IT integrators and automation systems;

- software developers;

- technology companies and startups;

- scientists and educators in Ukraine.

The Association of Industrial Automation of Ukraine, as the founder of the «Industry 4.0 in Ukraine» movement, has been actively promoting the cooperation of the effective community, development of partnership initiatives and projects since 2013. Important stages of the development of the «Industry 4.0 in Ukraine» movement were:

- Forum of the leaders of industrial automated control systems (2016), in which key development issues were formed; 
- AIAU Forum (2017), where the key development projects were presented for a general overview;

- AIAU Forum (2018), which approved the key strategic initiatives and directions for the development of the Industry 4.0 in Ukraine, which was included in the strategy of the development of Industry 4.0 in Ukraine.

The strategy identified the key factors of success [11]. It also includes the main directions of strategic development [12]. But the overall state of Ukrainian enterprises is still far from the application of priorities and technologies of Industry 4.0 [13]

Therefore, it is highly important is evaluation of the representatives of various organizations and companies of Ukraine on the priorities of the development strategy Industry 4.0 in Ukraine.

\section{Methods of research}

The methodology of the expert survey, comparison and generalization methods has been used.

The survey included a questionnaire survey of several blocks of questions:

- «Necessity of applying approaches to Industry 4.0 in national strategies of Ukraine».

- «Definition of industries where Ukraine has the best chance of taking a leading position on the development of Industry 4.0 approaches in the international arena».

- «Key factors for the success of Industry 4.0 strategy in Ukraine».

- «The main strategic initiatives for the development of Industry 4.0 in Ukraine».

122 respondents are participated in the survey, namely, representatives of 41 universities, 26 research institutes, 21 public organizations, 20 companies, 6 government agencies, 8 other organizations. Of these there are 17 members of AIAU and 105 representatives of various organizations and companies. The evaluation is conducted on a point scale, and representation of the results in percentage terms.

\section{Research results}

Association of Industrial Automation of Ukraine, as the founder of the «Industry 4.0 in Ukraine» movement since 2013 actively stimulated cooperation of the effective community, development of partnership initiatives and projects. Important stages of the development of the «Industry 4.0 in Ukraine» movement were the identification of the seventh main areas for the development of strategic initiatives Industry 4.0 in Ukraine [11]:

1. Institutionalizing the development of industrial hightech segments at the state level involves identifying target sectors of industrial high tech and stimulating high-tech products. Setting up system actions and programs to improve the readiness of Ukrainian industry to Industry 4.0.

2. Creation of an innovative ecosystem of industrial hightech foresees the creation of networks of the most effective structural elements of the ecosystem «Industry 4.0»Centers of expertise, research and development laboratories, technology parks, incubators and accelerators of startups 4.0, etc. Attraction of investments and funds to accelerate innovation development.

3. Accelerating clustering in the Industry 4.0 , both at the regional and national levels, and solving the challenges of developing policies and initiatives, launching regional development programs Industry 4.0, increasing value in the export growth chains.

4. Full digitalization of the key sectors of industry, energy, infrastructure and solving the tasks of stimulating the creation of regulatory incentives, the creation of road maps for digital transformation in target areas, and increasing the digital knowledge and skills of managers and staff.

5. Maximum integration of Industry 4.0 in the strategy of the defense complex and security of the country and the solving the task of launching special state programs for the transition of defense plants to technology 4.0 and enhancing their innovation.

6. Launching export programs for industry high tech sectors. Solving the tasks of creating a special trade mission for the export of products and services in the field of Industry 4.0. Implementation of annual exhibition programs (Hannover Messe), stimulating the launch of programs to improve the export potential of industrial high tech segments.

7. Internationalization and integration into the global space of Industry 4.0 and solving problems of integration into European programs, such as: Horizon 2020, I4MS/DIH, Factory of the Future, etc. Creating value-added integration programs at the level of world communities and countries, such as: Industrial Internet Consortium, etc. Promoting the transition to European standards (IEC/ISO).

The research results show that $79.4 \%$ representatives of various organizations and companies of Ukraine support the necessity of applying the approaches of Industry 4.0 in the national strategies of Ukraine, namely:

- Innovative strategy of Ukraine - support $89.67 \%$ of survey participants.

- Industrial Strategy of Ukraine - support $88.36 \%$ of survey participants.

- The Strategy for the Development of the Digital Economy

of Ukraine - support $89.5 \%$ of the survey participants.

- Export strategy of Ukraine - support $77.7 \%$ of the total survey participants.

- Strategy of the defense sector and security of Ukraine support $82.45 \%$ of the survey participants.

- Strategies for the development of high-tech industries support $90.81 \%$ of survey participants.

Concerning the definition of industries where Ukraine has the best chance to take the leading positions in the development of Industry 4.0 approaches in the international arena, $74.5 \%$ of the respondents expressed confidence that there are such areas, namely:

- «Programming in the field of industrial high-tech (creation of new software products, including new technologies 4.0)» $-85.24 \%$ of survey participants.

- «Designing industrial high-tech (electrical, mechanical, electronic, technological, construction, etc.)»- $70.98 \%$ of the survey participants.

- «Industrial automation and complex engineering (including the commissioning of complex industrial objects)»$69.18 \%$ of the survey participants.

- «Development and production of complex, small-scale or unique products» $-72.62 \%$ of survey participants.

Regarding key factors of success of the strategy for the development of Industry 4.0 in Ukraine, $76.73 \%$ of the survey participants supported, namely:

- «Consolidation of stakeholders 4.0 with government agencies in relation to the development and implementation 
of the industrial development program of Ukraine for the application of Industry 4.0 approaches» - $74.75 \%$ of the survey participants.

- «Stimulation of the IT sector to solve social problems of the domestic market of Ukraine» - $68.68 \%$ of the survey participants.

- «Creation of an Innovative Ecosystem of Ukraine» $80.81 \%$ of survey participants.

- «Integration into the European and World Chains of Value Added Creation 4.0» - $81.31 \%$ of the survey participants.

- «Accelerating the development of industrial segments in Ukraine with the application of Industry 4.0 approaches» $79.3 \%$ of the survey participants.

Regarding measures of implementation of the first strategic initiative «Strategy Industry 4.0 in Ukraine and development of industrial high-tech segments», the necessity was supported in Table 1.

Table 1

First strategic initiative measures

\begin{tabular}{|l|c|}
\hline \multicolumn{1}{|c|}{ Measures } & $\begin{array}{c}\text { Support by } \\
\text { survey par- } \\
\text { ticipants, \% }\end{array}$ \\
\hline $\begin{array}{l}\text { "Approval of Industry Development Strategy 4.0 in Ukraine } \\
\text { at the state level» }\end{array}$ & 78.68 \\
\hline $\begin{array}{l}\text { «Integration of the provisions of the development strategy } \\
\text { Industry 4.0 into the industrial and innovation strategy of } \\
\text { Ukraine» }\end{array}$ & 79.5 \\
\hline $\begin{array}{l}\text { "Establishment of an operating governing body under the } \\
\text { Cabinet of Ministers of Ukraine (CMU), which coordinates } \\
\text { the government's national development program Industry 4.0 } \\
\text { Ukraine» }\end{array}$ & 59.01 \\
\hline $\begin{array}{l}\text { "Recognition of target sectors of industrial high tech, which } \\
\text { are key to accelerated economic development of Ukraine» }\end{array}$ & 74.75 \\
\hline $\begin{array}{l}\text { «Implementation of the National Program for Improving the } \\
\text { Readiness of Industry of Ukraine to Industry 4.0» }\end{array}$ & 71.47 \\
\hline $\begin{array}{l}\text { «Implementation of financial instruments for stimulating } \\
\text { industrial high tech production» }\end{array}$ & 84.92 \\
\hline
\end{tabular}

Note: compiled by the authors based on the survey results

Concerning the measures of the implementation of the second strategic initiative «Creation of an Innovative Ecosystem of Industrial High-Tech Ukraine», the necessity was supported in Table 2.

\begin{tabular}{|l|c|}
\hline \multicolumn{1}{|c|}{ Measures } & $\begin{array}{c}\text { Support by } \\
\text { survey par- } \\
\text { ticipants, \% }\end{array}$ \\
\hline $\begin{array}{l}\text { "A complete independent audit of existing elements of the } \\
\text { ecosystem, such as the design bureau, the system of higher } \\
\text { educational institutions and the National Academy of Sciences, } \\
\text { scientific parks, etc.» }\end{array}$ & 74.26 \\
\hline $\begin{array}{l}\text { "Setting up of technology transfer from Ukrainian scientific } \\
\text { institutions, science parks, laboratories and centers of R\&D, } \\
\text { corporations to the final customers» }\end{array}$ & 81.63 \\
\hline $\begin{array}{l}\text { «Creation of networks of the most effective structural ele- } \\
\text { ments of the ecosystem «Industry 4.0 Ukraine»: centers of } \\
\text { expertise, R\&D laboratories, technology parks, incubators, } \\
\text { accelerators of startups 4.0» }\end{array}$ & 85.4 \\
\hline
\end{tabular}

Note: compiled by the authors based on the survey results
Concerning the implementation of the third strategic initiative «Accelerating clustering in the sphere of «Industry 4.0 Ukraine», both at the regional and national levels», the necessity was supported in Table 3.

Table 3

Third strategic initiative measures

\begin{tabular}{|l|c|}
\hline \multicolumn{1}{|c|}{ Measures } & $\begin{array}{c}\text { Support by } \\
\text { survey par- } \\
\text { ticipants, \% }\end{array}$ \\
\hline $\begin{array}{l}\text { "Formation of the policy of development of industrial clusters } \\
\text { and National Contact Points (NCP), which coordinate high } \\
\text { tech clusters» }\end{array}$ & 74.59 \\
\hline $\begin{array}{l}\text { "Launch of regional development programs of «ndustry 4.0 } \\
\text { Ukraine», including coordination with the regional Smart- } \\
\text { specialization» }\end{array}$ & 82.13 \\
\hline
\end{tabular}

Note: compiled by the authors based on the survey results

Regarding measures of implementation of the fourth strategic initiative «Full-scale digitalization of key sectors of industry and infrastructure», the necessity was supported in Table 4.

Table 4

Fourth strategic initiative measures

\begin{tabular}{|l|c|}
\hline \multicolumn{1}{|c|}{ Measures } & $\begin{array}{c}\text { Support by } \\
\text { survey par- } \\
\text { ticipants, \% }\end{array}$ \\
\hline $\begin{array}{l}\text { "Creating regulatory incentives for accelerating digitalization, } \\
\text { both among customers and innovators 4.0» }\end{array}$ & 82.13 \\
\hline $\begin{array}{l}\text { "Creation of road maps of digital transformation in the target } \\
\text { industries of Ukraine» }\end{array}$ & 77.37 \\
\hline $\begin{array}{l}\text { «Large-scale digitalization of industrial sectors of Ukraine } \\
\text { using best business practices» }\end{array}$ & 80.32 \\
\hline $\begin{array}{l}\text { «Increasing the digital knowledge and skills of managers and } \\
\text { personnel of enterprises of the target industries of Ukraine» }\end{array}$ & 87.37 \\
\hline
\end{tabular}

Note: compiled by the authors based on the survey results

Concerning the implementation of the fifth strategic initiative «Integration of the strategy «Industry 4.0 Ukraine» into the defense and security strategy», the necessity was supported in Table 5.

Table 5

Fifth strategic initiative measures

\begin{tabular}{|l|c|}
\hline \multicolumn{1}{|c|}{ Measures } & $\begin{array}{c}\text { Support by } \\
\text { survey par- } \\
\text { ticipants, \% }\end{array}$ \\
\hline $\begin{array}{l}\text { "Launch of special state programs to stimulate the transition } \\
\text { of defense plants to technology } 4.0 \text { and to solve the problems } \\
\text { of cyber security» }\end{array}$ & 77.86 \\
\hline $\begin{array}{l}\text { "Formation and integration of the tasks of cybersecurity of } \\
\text { the industrial Internet of things» }\end{array}$ & 78.68 \\
\hline $\begin{array}{l}\text { «Formation and integration into state programs on the preven- } \\
\text { tion of man-caused risks, control and monitoring systems of } \\
\text { critical infrastructure, critical objects and energy» }\end{array}$ & 80.16 \\
\hline
\end{tabular}

Note: compiled by the authors based on the survey results

Regarding the measures to implement the sixth strategic initiative «Launching programs of export of industrial high-tech sectors of Ukraine», the necessity was supported in Table 6. 
Table 6

Sixth strategic initiative measures

\begin{tabular}{|c|c|}
\hline Measures & $\begin{array}{c}\text { Support by } \\
\text { survey par- } \\
\text { ticipants, \% }\end{array}$ \\
\hline $\begin{array}{l}\text { «Implementation of annual exhibition programs, in particular } \\
\text { «Hannover Messe» }\end{array}$ & 78.36 \\
\hline $\begin{array}{l}\text { «Launch of special programs to improve the export potential } \\
\text { of enterprises of industrial high tech segments of Ukraine» }\end{array}$ & 78.52 \\
\hline
\end{tabular}

Note: compiled by the authors based on the survey results

Regarding the measures of implementation of the seventh strategic initiative «Internationalization and integration into the world of space Industry $4.0 »$, the necessity was supported in Table 7.

Table 7

Seventh strategic initiative measures

\begin{tabular}{|l|c|}
\hline \multicolumn{1}{|c|}{ Measures } & $\begin{array}{c}\text { Support by } \\
\text { survey par- } \\
\text { ticipants, \% }\end{array}$ \\
\hline $\begin{array}{l}\text { "Formation of integration programs into the space Indus- } \\
\text { try 4.0 EU, in particular in European programs (Horizon } \\
\text { 2020, I4M5/DIH, Factory of the Future and others)» }\end{array}$ & 83.44 \\
\hline $\begin{array}{l}\text { "Creating integration programs in the value chain and at the } \\
\text { level of world and European communities» }\end{array}$ & 81.14 \\
\hline $\begin{array}{l}\text { "Stimulation and support of the transition to the euro stan- } \\
\text { dards Industry 4.0 (IEC/ISO, etc.)» }\end{array}$ & 86.88 \\
\hline
\end{tabular}

Note: compiled by the authors based on the survey results

The measures within all seven initiatives of Industry 4.0 strategy have been rated by the respondents. The measures with the highest support by survey participants were presented in the tables above.

\section{SWOT analysis of research results}

Strengths. The study provides an assessment of the vision of representatives of various organizations and companies of Ukraine on the priorities of the development strategy Industry 4.0 in Ukraine. It's important, because Ukrainian Industry 4.0 strategy is a great step towards implementation of Industry 4.0.

Weaknesses. The survey was only conducted among 122 representatives including 41 universities, 26 research institutes, 21 public organizations, 20 companies, 6 government agencies, 8 other organizations, but attraction of more respondents can increase research accuracy.

Opportunities. The result of this research can be used by institutional organizations of state power of Ukraine in the formation of industrial policy of Ukraine.

Threats. Applying the approaches of Industry 4.0 in the national strategies of Ukraine may require consideration of more specific issues.

\section{Conclusions}

1. A questionnaire to access the vision of various stakeholders on the development of Industry 4.0 strategy in Ukraine is developed based on the priority measures and initiatives proposed in the Ukrainian Industry 4.0 strategy.

2. The survey among representatives of various organizations and companies of Ukraine was conducted during the events of the project Advocacy of pro-European changes in national innovation policy supported by the European Commission.

3. The analyses of the research results establishes the priority measures for the implementation of the Ukrainian strategy Industry 4.0 (supported by more than $80.0 \%$ of all respondents), taking into account the priority ranking.

\section{References}

1. Was ist Industrie 4.0? (2019). Plattform-i40.de. Available at: https://www.plattform-i40.de/PI40/Navigation/DE/Industrie40/ WasIndustrie40/was-ist-industrie-40.html

2. Industry 4.0: Building the digital enterprise (2016). PWC. Global Industry 4.0 Survey. Available at: https://www.pwc.com/ gx/en/industries/industries-4.0/landing-page/industry-4.0-building-your-digital-enterprise-april-2016.pdf

3. The Industry 4.0 paradox (2018). Deloitte. Available at: https:// www2.deloitte.com/content/dam/Deloitte/de/Documents/energy-resources/Industry \%204.0\%20Paradox_Report.pdf

4. Industrie 4.0 in a Global Context (2016). Acatech STUDY Available at: https://www.plattform-i40.de/PI40/Redaktion/ EN/Downloads/Publikation/industrie-40-in-a-global-context. pdf? _blob=publicationFile $\& \mathrm{v}=3$

5. Recommendations for implementing the strategic initiative INDUSTRIE 4.0 (2013). DIN. Available at: https://www.din.de/ blob/76902/e8cac883f42bf28536e7e8165993f1fd/recommendations-for-implementing-industry-4-0-data.pdf

6. Industry 4.0: the fourth industrial revolution - guide to Industrie 4.0 (2019). i-SCOOP. Available at: https://www.i-scoop.eu/ industry-4-0/

7. Marr, B. (2019). What is Industry 4.0? Here's A Super Easy Explanation For Anyone. Forbes.com. Available at: https://www. forbes.com/sites/bernardmarr/2018/09/02/what-is-industry-40-heres-a-super-easy-explanation-for-anyone/\#56548d789788

8. What is Industry 4.0? The Industrial Internet of Things (2019). Epicor.com. Available at: https://www.epicor.com/en-us/resource-center/articles/what-is-industry-4-0/

9. Embracing Industry 4.0 and Rediscovering Growth (2019). Bcg.com. Available at: https://www.bcg.com/capabilities/operations/embracing-industry-4.0-rediscovering-growth.aspx

10. Shcherbatenko, O. (2019). Prospects and obstacles of the digital economy of Ukraine. Na chasi. Available at: https://nachasi. com/2018/01/29/what-makes-ukraine-digital

11. Yurchak, O. (2019). Ukrainian Industry Strategy $4.0-7$ trends. Industry 4.0 in Ukraine. Available at: https://industry4-0-ukraine. com.ua/2019/01/02/ukrainska-strategiya-industrii-4-0-7-napriankiv-rozvutku/

12. National Industry Strategy 4-0 (2019). Project for the Cabinet of Ministers of Ukraine. APPAU. Available at: https://appau. org.ua/en/pubs/national-strategy-4-0/

13. Fedak, M. (2018). Industry 4.0 in mechanical engineering: the state of Ukraine and prospects for development. APAAU. Available at: https://industry4-0-ukraine.com.ua/2018/10/18/ аналітичний-звіт-індустрія-4-0-в-машино/

Nikitin Yuri, Doctor of Technical Sciences, Professor, Sector of Innovation and Technology Transfer, V. Bakul Institute for Superhard Materials of the National Academy of Sciences of Ukraine, Kyiv, Ukraine, e-mail: ynikitin2016@gmail.com, ORCID: http:// orcid.org/0000-0002-8361-7115

Kulchytskyy Oles, Project Manager, Non-Governmental Organization «Agency of European Innovations», Lviv, Ukraine, e-mail: oles.kulchytskyy@aei.org.ua,ORCID: http://orcid.org/00000003-0951-6356 